\title{
Progenitors for the Corneal Endothelium and Trabecular Meshwork: A Potential Source for Personalized Stem Cell Therapy in Corneal Endothelial Diseases and Glaucoma
}

\author{
Wing Yan Yu, ${ }^{1}$ Carl Sheridan, ${ }^{2}$ Ian Grierson, ${ }^{2}$ Sharon Mason, ${ }^{2}$ Victoria Kearns, ${ }^{2}$ \\ Amy Cheuk Yin Lo, ${ }^{1,3}$ and David Wong ${ }^{1,3,4}$ \\ ${ }^{1}$ Eye Institute, Li Ka Shing Faculty of Medicine, The University of Hong Kong, Pokfulam, Hong Kong \\ ${ }^{2}$ Department of Eye and Vision Science, Institute of Ageing and Chronic Disease, University of Liverpool, \\ University Clinical Departments Building, The Duncan Building, Daulby Street, Liverpool L69 3GA, UK \\ ${ }^{3}$ Research Center of Heart, Brain, Hormone and Healthy Aging, Li Ka Shing Faculty of Medicine, \\ The University of Hong Kong, Pokfulam, Hong Kong \\ ${ }^{4}$ St. Paul's Eye Unit, Royal Liverpool University Hospital, Prescot Street, Liverpool L7 8XP, UK
}

Correspondence should be addressed to Carl Sheridan, c.sheridan@liverpool.ac.uk and David Wong, shdwong@hku.hk

Received 10 August 2011; Accepted 8 September 2011

Academic Editor: Ken-ichi Isobe

Copyright (c) 2011 Wing Yan Yu et al. This is an open access article distributed under the Creative Commons Attribution License, which permits unrestricted use, distribution, and reproduction in any medium, provided the original work is properly cited.

\begin{abstract}
Several adult stem cell types have been found in different parts of the eye, including the corneal epithelium, conjunctiva, and retina. In addition to these, there have been accumulating evidence that some stem-like cells reside in the transition area between the peripheral corneal endothelium (CE) and the anterior nonfiltering portion of the trabecular meshwork (TM), which is known as the Schwalbe's Ring region. These stem/progenitor cells may supply new cells for the CE and TM. In fact, the CE and TM share certain similarities in terms of their embryonic origin and proliferative capacity in vivo. In this paper, we discuss the putative stem cell source which has the potential for replacement of lost and nonfunctional cells in CE diseases and glaucoma. The future development of personalized stem cell therapies for the CE and TM may reduce the requirement of corneal grafts and surgical treatments in glaucoma.
\end{abstract}

\section{Introduction}

Rapid progress in stem cell research in recent years provides new hope for the treatment of various previously incurable diseases. The basic treatment principle is to replace lost or damaged cells with healthy ones derived from stem cells and/or stimulate endogenous regeneration via paracrine effects mediated by the transplanted stem cells $[1,2]$. Stem cells can reasonably be categorized into three main types according to their origins: embryonic stem (ES) cells, induced pluripotent stem cells (iPSCs), and adult stem cells. The focus of this paper will concern a specific region of the eye, namely, the adult stem cells of the human corneal endothelium (CE) and neighbouring trabecular meshwork (TM), there will be considerable overlap in the techniques applied to the differentiation of cells and obstacles to be addressed before regeneration therapies are available.

\section{Stem Cell Overview}

Whilst ES cells have numerous advantages in research such as their unlimited capacity to self-renew and pluripotency allowing them to differentiate into any cell type in the body, the fear of teratoma formation, immune-rejection issues, and ethical concerns regarding the destruction of embryos have slowed their progress towards clinical trials.

The research field of iPSCs has rapidly gained momentum since the discovery by Takahashi and Yamanaka [3]. iPSCs afford an advantage in that an autologous approach may be possible and as such circumventing the ethical and immunological disadvantages of ES cells. However, there are major safety concerns that involvement of retroviral or lentiviral vector integration in iPSCs engineering may cause genomic disruption and oncogenesis [4-6]. Besides, after the reports proving iPSCs retained epigenetic memory from 
the somatic cell of origin $[7,8]$, questions have been raised whether iPSCs are completely pluripotent like ES cells, as how far back they are reprogrammed will influence their directed differentiation potential. Despite the bright future iPSCs may have, extensive efforts and a measured scientific approach are required to guarantee safety and production quality, to understand more about the molecular signaling and pathways, and to find out reliable differentiation protocols of iPSCs before transplantation can be done in patients.

Adult stem or progenitor cells are also referred to as somatic stem cells. They reside in many adult tissues such as the bone marrow, skeletal muscle, heart, brain, skin, and limbus (summarized in [9]). Although they are not pluripotent, they still retain high plasticity. Their ethical superiority over embryonic stem cells and autologous origin avoiding immunological suppression after surgery makes them a popular stem cell source for small-scale clinical application $[10,11]$. Adult stem cells are enriched in locations that are very close to the target tissue, as such, they may have more direct and faster access to the site of injury when compared with other stem cell types [9]. In addition, they have already undergone critical developmental stages, which render them comparatively easier to commit to the cell types desired [12, 13]. Understandably, difficulties such as their isolation, expansion efficiency due to limited cell numbers and integration and survival in the host tissue still remain to be unravelled. Adult stem cells, albeit with their own limitations, may be a relatively safer and more ethical alternative cell source for therapeutic use at present.

In the eye, the most successful stem-cell-based therapy to date has been the use of limbal epithelial stem cells to regenerate the corneal epithelium [14]. Apart from limbal epithelial stem cells, intensive research has been done on different niches of adult ocular stem cells, such as conjunctival epithelial and retinal stem cells, aiming for ocular repair and regeneration $[13,15,16]$. One niche of cells that has had relatively limited attention and may be of considerable clinical value (which is the focus of this paper) are the progenitor cells located in the transition zone between the periphery of the $\mathrm{CE}$ and the anterior extension of the TM, which is known as the Schwalbe's Ring region. In the recent decade, more and more evidence emerged to support the idea that these progenitors may be able to provide new cells for the CE, TM, or possibly both. This opens up a new prospect on research using these intriguing progenitors to treat $\mathrm{CE}$ diseases and glaucoma. In this paper, we will review the biological properties of CE and TM cells, summarize and discuss the evidence suggesting the presence of stem-like cells in the transition area, and, in addition, outline how these cells can be used for regeneration.

\section{CE and TM: Structure, Function, and Embryology}

3.1. Corneal Endothelium. Cornea is the transparent tissue located at the front of the eye which provides approximately two-thirds of the total ocular refractive power (Figure 1(a)). It consists of five layers: the multilayered epithelium,
Bowman's membrane, the stroma, Descemet's membrane, and the endothelium. CE is on the posterior surface of the cornea facing the anterior chamber. It is composed of a single layer of regularly arranged hexagonal and pentagonal cells which are around $5 \mu \mathrm{m}$ thick and $20 \mu \mathrm{m}$ in diameter [17]. The crucial function of the CE is to maintain corneal transparency by regulating corneal hydration while allowing nutrients from the aqueous to diffuse back to the avascular cornea. The endothelium accomplishes this by a pumpleak model. It serves as a "leaky" barrier to permit selective permeability of the nutrients but prevents bulk fluid flow into the stroma. At the same time, it actively removes excess fluid from the stroma into the anterior chamber through ionic fluid pumps to prevent corneal swelling. In addition to the barrier and pump functions, the endothelial cells are responsible for the synthesis of Descemet's membrane, which is the basement membrane where the endothelium resides $[18,19]$.

3.2. Trabecular Meshwork. The anterior chamber of the eye is bordered anteriorly by the $\mathrm{CE}$ and posteriorly by the iris. At the periphery of the chamber, there lie the TM, scleral spur, ciliary body, and iris root, which form the anterior chamber angle (Figure 1(b)). The TM extends from an anatomical position called Schwalbe's line, which marks the end of Descemet's membrane, to the ciliary body and iris root at their junction. There is a specific cell population near the transition area (Schwalbe's line) between cornea and meshwork, and this will be discussed in detail in Section 5 . Together with Schlemm's canal, the collector channels, and aqueous veins, the TM forms the major structure for aqueous humour outflow [17]. Aqueous humour is produced by the ciliary body and passes through the pupil into the anterior chamber. It subsequently leaves the eye through the TM into Schlemm's canal, then from there to the intrascleral plexus, and finally to the episcleral venous system [20].

The TM is a porous tissue comprised of three regions: the innermost uveal meshwork which is chord-like in structure, the deeper corneoscleral meshwork with flattened sheet-like trabeculae, and the juxtacanalicular connective tissue (also called cribriform layer or endothelial meshwork) which links the corneoscleral trabeculae with the inner wall endothelium of Schlemm's canal $[17,21]$. The trabecular lamellae or beams contain collagenous cores surrounded by endothelial cells, and the lamellae are bridged by the TM cells [22]. The corneoscleral and uveal meshwork do not provide much resistance to aqueous outflow and Grant showed that aqueous outflow facility was not affected even if the inner parts of the TM were excised [23]. The outflow resistance resides primarily at the region near the juxtacanalicular connective tissue and the endothelial lining of Schlemm's canal [22]. Since the Schlemm's canal is shorter than the TM in the anteroposterior direction, the TM can also be divided into the anterior nonfiltering and posterior filtering portions.

3.3. Embryology. During embryogenesis, the neural ectoderm, the surface ectoderm, the neural crest, and, to a lesser extent, the mesoderm are involved in the development of 


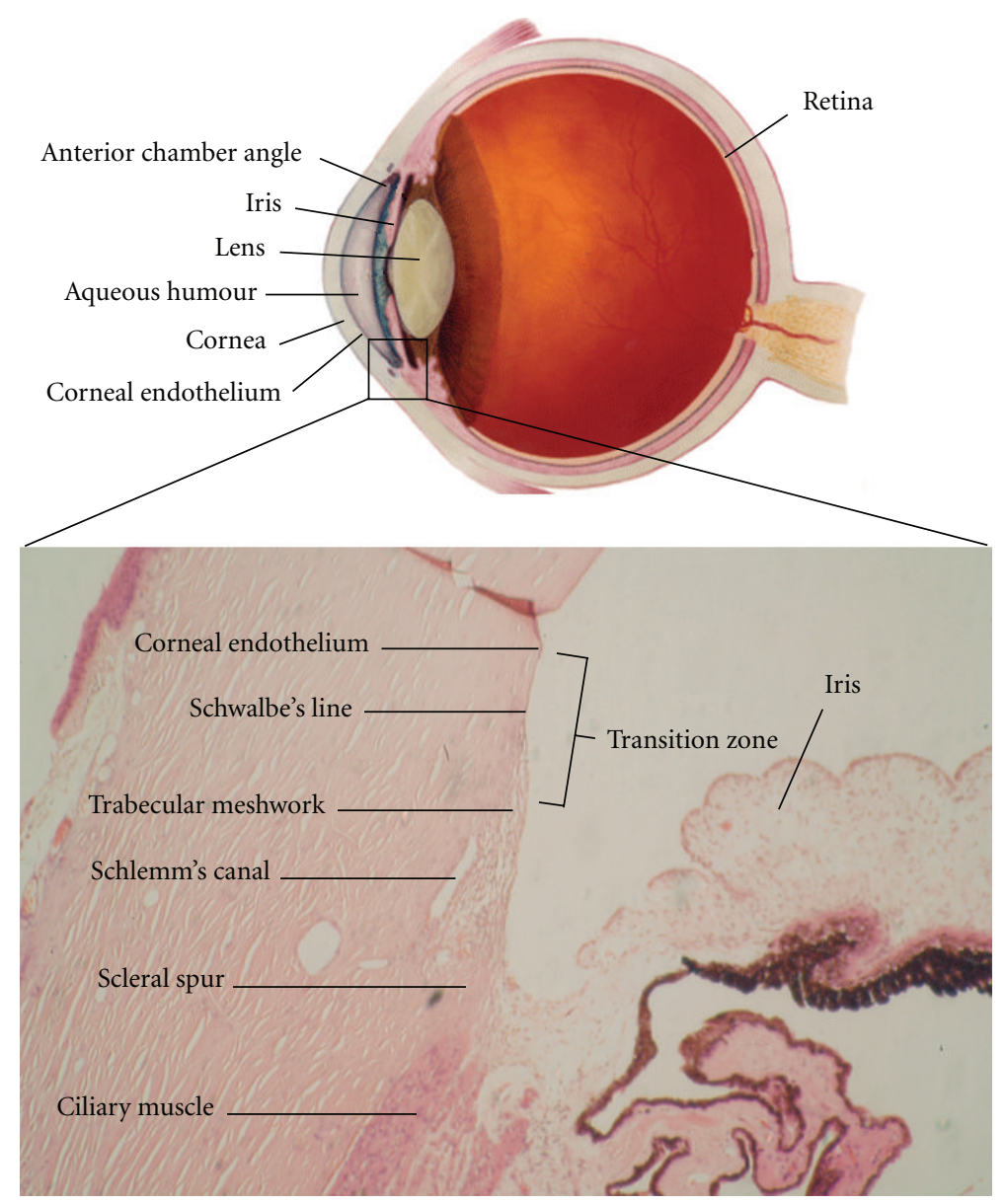

(a)
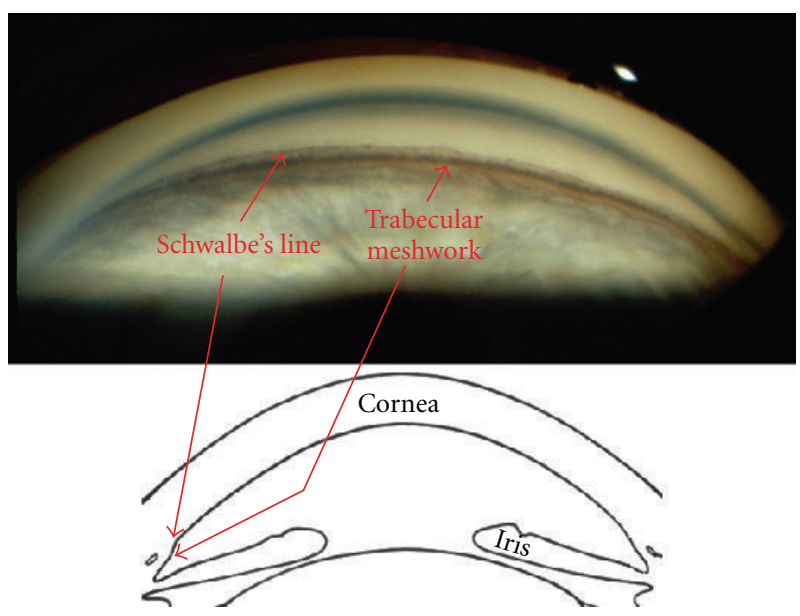

(b)

Figure 1: (a) Schematic diagram of the human eye and transverse section of haematoxylin and eosin stained chamber angle tissues $(\times 100)$. (b) Anterior chamber angle as viewed in gonioscopy.

the eye. The CE and TM are both derived from the neural crest. They are formed from the first wave of neural crestderived mesenchymal cells migrating between the surface ectoderm and the lens. The development of the cornea begins at approximately 33 days of postfertilization [24]. At around the 40th day, a double row of flattened cells posterior to the basal lamina of the corneal epithelium is produced by the mesenchyme and it develops into the monolayer of CE by the 18th week $[18,24,25]$. At this time, the CE extends nearly to the angle recess. This endothelial membrane covering the angle recess starts to regress at around 15 weeks of gestation [25]. 
The primitive TM is formed at around the fourth month. It consists of a triangular mass of undifferentiated mesenchymal cells. During the seventh month, these cells flatten and become slightly separated from each other, and the cavities are filled with extracellular fibers. The fibers are then organized to form the trabecular lamellae or beams. Some cells with a stellate phenotype form the juxtacanalicular layer of the TM. The complete morphogenesis of the TM is finished around birth [24-27].

These tissue developments require specific gene regulatory networks in which many transcription factors and molecular signals are involved. Although the detailed developmental networks are still not well defined, some contributing factors are known. Cvekl and Tamm performed a comprehensive review of the transcription factors that are associated with the anterior segment morphogenesis [26]. They include PAX6, PITX2, PITX3, FOXC1, FOXE3, LMX1B, and MAF, where PAX6 is the essential regulator for eye development in different organisms $[26,28,29]$. It is involved in controlling neural crest migration and thus has a critical role in early formation of the CE and TM $[30,31]$. The CE did not develop in Pit $x 2^{-/-}$ and $\mathrm{FoxCl}^{-/-}$mice and the TM was abnormally formed [32-35]. LMX1B was shown to have a direct link to the dysgenesis of the TM [36]. Whilst these transcription factors clearly have an important role, some other transcription factors also influence CE and TM development [37-41]. In addition, specific signaling molecules also play a key role in coordinating the anterior segment growth. This is borne out with transforming growth factor (TGF)-beta 2 knockout mice which developed a much thinner cornea with CE failing to develop [42, 43]. Moreover, heterozygous deficiency of BMP4 resulted in absent or hypoplastic TM and Schlemm's canal, and profound extracellular matrix deficiencies in the TM [44]. For the role of different growth factors during embryogenesis and differentiation of the eye, readers are referred to the review by Tripathi et al. [45].

\section{Biological Properties of CE and TM Cells}

4.1. Cellular Characteristics and Markers Identification. CE cells adjoin one another with extensive interdigitations and are interconnected by tight and gap junctions. The tight junctions do not completely encircle the cells so that the endothelium can allow selective permeability for nutrients. The apical sides of the cells contain a band of actin filaments which helps maintain cell shape and barrier function and facilitate cell migration in wound healing [46]. Ultrastructurally, the endothelial cells have a large nucleus and contain numerous mitochondria, a prominent endoplasmic reticulum and Golgi apparatus, which are the characteristic features for cells metabolically active in transport, synthesis, and secretory function [18].

Although the CE is named "endothelium," it differs from the vascular endothelium. The $\mathrm{CE}$ is derived from the neural crest, whereas the vascular endothelium is from the mesoderm [25]. Additionally, the CE does not contain Weibel-Palade bodies nor express factor VIII, which are the typical vascular endothelium markers [47]. The CE displays an unusual combination of immunoreactions to antibodies against intermediate filaments vimentin and neurofilaments, as well as neural markers including neural cell adhesion molecule, neuron specific enolase, and S-100 protein [4750]. These observations are not surprising when we trace back the origin of the CE. However, there have been controversies about the cytokeratin (CK) profile in the CE. CK8 and CK18 expressions in human CE cells were described in several studies [51-53] but not in others [54, 55]. Merjava et al. proposed that the variable results were due to different processing approach and antibody sensitivities [53]. The labeling of CK7 and CK19 in the CE is even more controversial $[51,55,56]$. To date, there has not been a specific marker for the CE. One can mainly distinguish them by their hexagonal morphology and evaluate their function using an Ussing chamber to measure the transport activity [57-59].

The TM cells bridge the intertrabecular spaces through cytoplasmic extensions, and adjacent cells are firmly connected to each other by desmosomes [22]. Electron microscopic studies revealed that gap junctions form the main intercellular connection between the TM cells [60]. The major actin distributions in the TM cytoplasm are straight stress fibers [61]. However, cross-linked actin networks (CLANs) have also been detected in human and bovine TM tissues $[61,62]$. Similar to CE cells, there are no specific biomarkers to identify TM cells. It has been shown that the TM cells express vimentin, non-muscle actin, aquaporin-1, acetylated and acetoacetylated low-density lipoproteins, and the alpha-2 adrenergic receptor [49, 63-66]. The expression of myocilin in TM cells was increased after dexamethasone treatment [67]. Nevertheless, these proteins are also present in other cell types, making it difficult to use a single marker to identify TM cells. Some other potential TM markers including the matrix GLA protein and chitinase-3-like-1 were reported by other groups $[68,69]$.

Despite the lack of specific marker proteins, the TM cells possess some typical physiological characteristics. Rohen and Van der Zypen was the first to show that TM cells have phagocytic capacity [70]. It is believed that the phagocytosis helps remove debris in the circulating aqueous humour [71]. Besides, meshwork cells can synthesize a variety of extracellular materials including collagens, glycoproteins, and glycosaminoglycans (see [72] for review). The replacement and modification of the extracellular matrix compensates the gradual washout of materials during aqueous perfusion, so that the necessary outflow resistance is maintained. Moreover, the presence of contractile filaments in the TM cell cytoplasm indicates their contractility [73, 74]. It was found that substances that contract meshwork cells decrease the aqueous outflow facility and vice versa [75].

Both the CE and TM cells are exposed to continuous workload throughout lifetime, yet, they have limited proliferative capacity in situ to replace lost cells under normal circumstances $[76,77]$. In the $\mathrm{CE}$, the surrounding cells spread and slide to fill the gaps caused by cell loss. The endothelial cells are arrested in G1-phase of the cell cycle [76]. Bovine TM cells were also shown to be locked in 


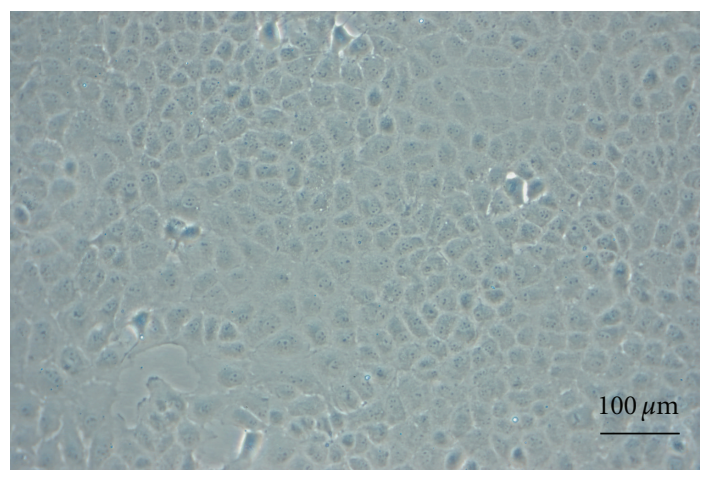

(a)

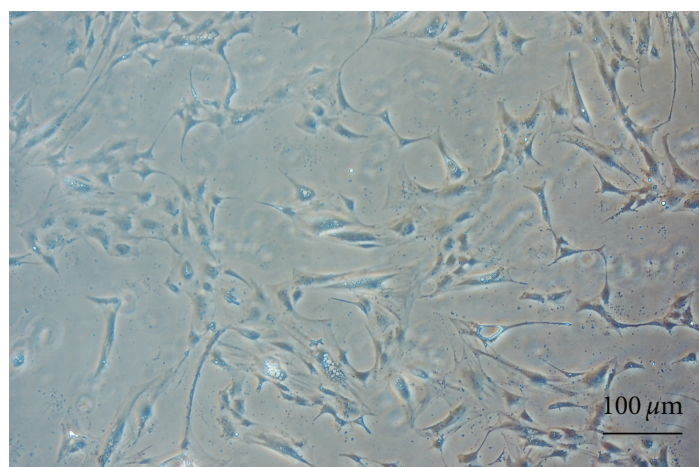

(b)

Figure 2: (a) Corneal endothelial and (b) trabecular meshwork cells cultured in vitro.

G0/G1-phase [77]. Although both cell types can be grown in culture, they are contact inhibited [76]. The division rate of bovine TM cells decreased to negligible amounts when they were in contact and formed gap junctions [78].

4.2. Consequence of Cell Loss or Malfunction. There are approximately 4,000 CE cells per $\mathrm{mm}^{2}$ at birth, but the cell density decreases with age at a rate of $0.6 \%$ per year throughout life [79]. The cell number is usually adequate to maintain normal corneal function for a lifetime. However, besides the factor of ageing, endothelial cell loss can also occur due to disease, trauma, and surgery. These may result in a higher cell depletion rate than normal, leading to endothelial failure and hence, loss of visual acuity. In order to maintain adequate corneal function, a minimum level of 400 to 700 endothelial cells per $\mathrm{mm}^{2}$ is required and the cells need to be of uniform size and shape [18]. Hence, corneas for grafting need to be screened for endothelial health and cell numbers before they are accepted. Some ocular diseases are manifested by abnormal endothelial cells. Fuch's endothelial dystrophy is a corneal disease involving malfunction of the endothelial cells, in which irregular warts or excrescences of Descemet's membrane are secreted. The excrescences are collagenous secretions (known as guttata) deposited at the posterior surface of the membrane, causing disruption of the overlying endothelial cells and thus compromise endothelial function $[18,80]$. Another disease attributable to aberrant $\mathrm{CE}$ is the iridocorneal endothelial (ICE) syndrome. The endothelium proliferates and migrates outward to the TM and across the angle onto the surface of the iris, which may progress to glaucoma, corneal decompensation, or both $[81,82]$.

The TM cellularity decreases with age as well. Alvarado et al. reported a cell loss rate of $0.58 \%$ per year [83]. This is comparable to that seen in the CE. It was estimated that there were 750,000 cells in the meshwork at 20 years of age but the number decreased down to around 400,000 by 80 years [84]. Other age-related changes in the TM include trabecular thickening, trabecular fusions, and alterations to the extracellular material in the juxtacanalicular meshwork; all of which would increase the aqueous outflow resistance and subsequently the intraocular pressure (IOP) [71]. Pathologically elevated intraocular pressure is the major risk factor in primary open angle glaucoma (POAG). Indeed, these agerelated changes are intimately linked to the glaucomatous alterations found in POAG patients. The glaucomatous eyes were found to have significantly more cellular losses compared with age-matched normal eyes [85]. This is believed to precipitate the decrease in drainage facility. When cell loss is progressive, trabecular thickening and fusion may develop due to adhesions of the denuded portions of the trabeculae. Furthermore, accumulation of extracellular materials and meshwork cell hyperplasia in glaucomatous TM that are believed to obstruct the outflow pathway was also documented [71]. Hence, TM cells are essential to maintain a healthy meshwork for aqueous drainage.

4.3. Culture In Vitro. In spite of the restricted replication capacity in vivo, the CE and TM cells can be grown in culture under appropriate conditions. Figure 2 shows the in vitro culture of bovine CE and TM cells. It has been demonstrated that fibroblast growth factor (FGF) stimulates the proliferation of CE and TM cells [86-88]. Hepatocyte growth factor (HGF) is also a competent mitogen for both CE and TM cells in a dose-dependent manner [89, 90]. Culturing of CE cells on dishes coated with collagen type IV, laminin, or fibronectin favoured the formation of a typical hexagonal monolayer [86]. Hyldahl reported that the addition of insulin-like growth factor-1 (IGF-1) and epidermal growth factor (EGF) stimulates CE cells to initiate DNA synthesis [91]. Treatment of TM cells with plateletderived growth factor (PDGF) can also increase their cell division. Besides, it enhances the phagocytic activity and promotes extracellular matrix secretion [92]. IGF-1 was shown to promote the incorporation of $[3 \mathrm{H}]$ thymidine in TM cells, whereas vascular endothelial cell growth factor (VEGF) restrained cell growth [93]. Studies have revealed that TGF-beta, which is present in the aqueous humour, inhibits TM cell proliferation and suppresses S-phase entry of CE cells $[94,95]$. Table 1 shows a summary of the mentioned growth factors effects on CE and TM cell proliferation in vitro. 
TABLE 1: The influence of growth factors on CE and TM cell proliferation.

\begin{tabular}{lcc}
\hline Growth factor & Corneal endothelium & Trabecular meshwork \\
\hline EGF & ++ & ++ \\
bFGF & + & ++ \\
HGF & + & ++ \\
PDGF & ++ & + \\
IGF-1 & + & + \\
TGF & - & -- \\
VEGF & & - \\
\hline
\end{tabular}

Both the CE and TM cells are unique cell types in the eye. They do not normally replace themselves once they are lost in aging or diseases. To date, there has been no cell therapy for the treatment of CE and TM related diseases. A lot of unknown facts about the regenerative capacity of TM or CE still exist. Thus, the potential to repair or replace the CE and $\mathrm{TM}$ is an important area that needs to be explored.

\section{Evidence of Stem-Like Cells in the Schwalbe's Ring and Their Therapeutic Implication}

Stem cells are undifferentiated cells which can renew themselves indefinitely and produce one or more progenies through symmetric and asymmetric division, whereas progenitor cells have relatively limited self-renewal capacity and more restricted differentiation abilities. As mentioned earlier, stem/progenitor cells have been identified in various adult mammalian tissues. They are crucial for tissue renewal and regeneration. These adult stem cells have some key characteristics, including small cell size and high nucleus to cytoplasm ratio, high proliferative potential, slow cell cycle, and poor differentiation capacity with primitive cytoplasm [96]. They reside within a specialized microenvironment called niche, which offers protection and nourishment to the cells [97]. It is believed that adult stem cells have huge ethical and immunological advantages over embryonic stem cells as a future therapeutic option.

In the eye, accumulating evidence reveals that there is a population of stem-like cell located in the transition area between the periphery of the $\mathrm{CE}$ and the anterior nonfiltering portion of the TM (Figure 3). This transition region is referred to as Schwalbe's Ring. Schwalbe's line marks the peripheral termination of the Descemet's membrane and can be viewed clinically in gonioscopy (Figure 1(b)). In 1982, Raviola identified a population of unusual cells located just beneath the Schwalbe's line in rhesus monkey, which she called Schwalbe's line cells [98]. These cells are different from the typical CE and TM cells and have distinct ultrastructural features. As described, these cells "form a discontinuous cord, oriented circumferentially at the corneal periphery and deep to the CE lining of the anterior chamber." They morphologically resembled whorled multilamellar bodies of type II alveolar epithelial cells of the lung and were proposed to be secretory. Stone et al. found that these cells were immunoreactive to neuron-specific enolase, suggesting that they may have neuroregulatory function in the anterior segment [99]. Rittig and colleagues later reported intense staining of the enzyme hyaluronan synthase in Schwalbe's line cells, indicating their hyaluronan production ability [100]. Samuelson et al. documented Schwalbe's line cells in canine eyes as well [101]. In general, there seems to be a distinct cell population in the transition area, while their function is still unclear.

Not much attention was paid to Schwalbe's line cells until there was more evidence supporting the presence of stem/progenitor cells in this transition zone. The idea came primarily from the observation of an increase in TM cell division localized to the anterior nonfiltering portion of the TM after argon laser trabeculoplasty (ALT) [102]. ALT is a glaucoma therapy which aims at lowering the IOP. The principle of this laser procedure is not to make drainage holes through the TM, but to "blanch" the tissue which creates superficial burn restricted to the uveal meshwork [103]. The exact mechanism by which this treatment lowers IOP is not known, however, one of the possible mechanisms of action is the repopulation of the TM by stimulating cell division [104]. Indeed, several studies have shown marked tritiated thymidine incorporation into the TM cells following ALT in different species $[102,105,106]$. Acott and colleagues demonstrated a four-fold increase in TM cell division in human laser-treated explants compared with untreated controls [102]. They found that more than $60 \%$ of the cell division was initially localized to the anterior nonfiltering region of the TM and these proliferative cells migrated to repopulate the burn lesions afterwards. It appears that these cells are putative stem cells that are invigorated after ALT to repopulate the TM, possibly through the release of growth factors and cytokines. Due to their location at the insertion region into the cornea just beneath Schwalbe's line, Kelley have named them the "TM insert cells" [107].

Although ALT can lower the IOP successfully and, to some extent, repopulate the cell-deficient TM in glaucoma, uncontrolled repair process that occurred in the tissue may become a detrimental consequence. An abnormal corneal and/or trabecular endothelial cell sheet covering the anterior uveal meshwork was observed in some glaucoma patients after ALT $[108,109]$. In some cases, they can grow extensively and block the aqueous outflow subsequently, leading to the failure of the surgery. Alexander et al. observed this aberrant endothelial membrane as well in normal human TM which was subjected to ALT [110]. They found that laser placed close to Schwalbe's line advanced the endothelial extension. It was believed that these repopulating processes after ALT involve migration of a specialized population of cells extending from the Schwalbe's line region [109, 110].

In addition to the observations in the TM, a significantly higher cell density at the peripheral $\mathrm{CE}$ also suggests that stem-like cells may be present in the peripheral transition region to provide differentiated CE cells $[111,112]$. Otherwise, the cell density should be uniform all over the CE. It has been documented in the literature that at least some CE cells have the ability to divide under specific circumstances [113116]. It was found that the peripheral CE cells retained higher replication competence than those in the central and this 


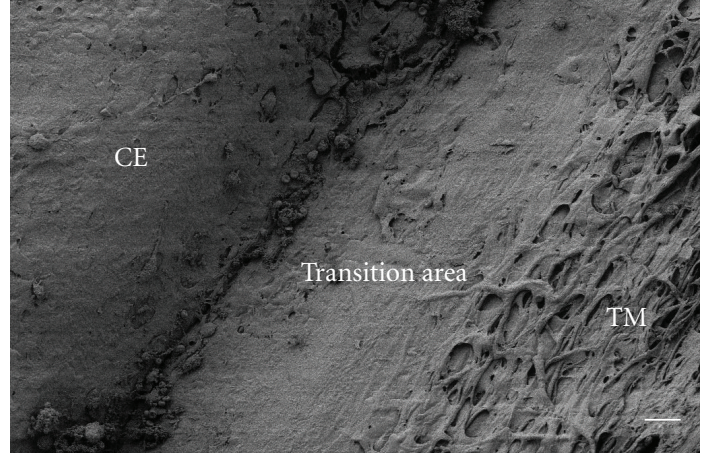

(a)

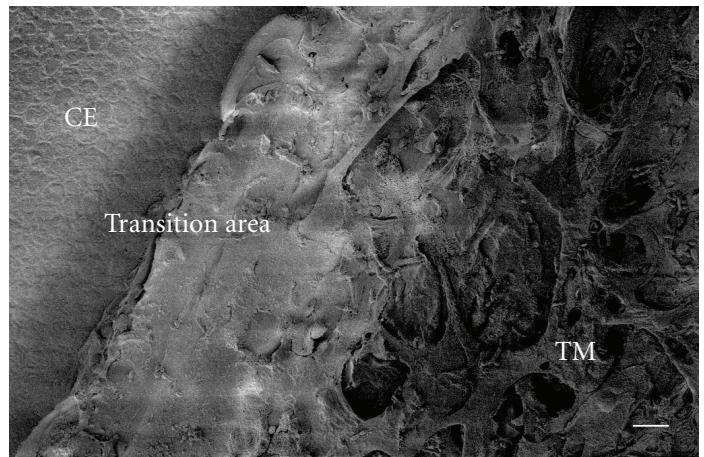

(b)

Figure 3: Scanning electron micrographs of (a) human and (b) bovine eyes, showing the transition between the peripheral cornea and anterior portion of the trabecular meshwork. There is a distinct transition area in the human tissue but the transition is more abrupt in the bovine one. The samples were coated with gold and imaged at an accelerating voltage of $4 \mathrm{kV}$ and a working distance of $8 \mathrm{~mm}$ using a SE2 detector (Gemini LEO 1550 SEM). Scale bar $=20 \mu \mathrm{m}$.

was independent on the donor age [117]. Moreover, corneal grafts in hosts who retain the peripheral endothelium survive much longer than grafts in hosts with CE cell loss [118]. Persistent precursors from the host cornea may explain the enhanced long-term survival of grafts. Interestingly, Balachandran et al. reported in a case series that in spite of complete graft detachment after Descement membrane endothelial keratoplasty, spontaneous recovery of corneal transparency was observed in two patients [119]. They suggested that "endothelial transfer, migration, regeneration, or a combination thereof from either the donor or the recipient may explain the visual recovery." Schwartzkopff et al. later reported in vivo re-endothelialization following complete endothelial cell loss of the grafted donor cornea in rats and suggested that peripheral CE cells in recipients can support the regeneration [120]. These findings indicate that $\mathrm{CE}$ may have some sort of regenerative capacity under specific conditions, which is not consistent with the long-term belief that they do not divide in vivo [76]. In particular, the peripheral CE seems to be the regenerative zone in these conditions. As such, research of the Schwalbe's Ring region has become even more interesting, as the precursor cells in this transition area may be able to supply new cells for both the TM and CE.

In recent years, molecular marker studies supply more supportive data for the stem cell niche at the transition zone. Whikehart et al. detected telomerase activity, which is a stem cell maker, in the peripheral cornea [121]. They also observed bromodeoxyuridine (BrdU) labeling, which is a marker for cell division, in the TM and posterior limbus. The BrdU incorporation increased and extended into the $\mathrm{CE}$ in response to mechanical wounding. McGowan et al. showed that cells at the transition region express stem cell makers nestin, alkaline phosphatase, and telomerase [122]. Following corneal wounding, additional putative stem cell markers (Oct3/4, Wnt 1 ) and differentiation markers (Pax6, Sox2) were observed. It was suggested that the putative stem cells in the transition area migrated to renew the wounded CE. To date, there has been no specific marker for this population of putative stem cells despite the observation of a different immunohistochemical profile in the CE, TM insert cells, and TM cells. Neuron-specific enolase was found to locate at the anterior but not posterior portion of the human TM [49]. Ankyrin G and human milk fat globule protein (HMFG, also known as breast antigen 46) were highly expressed in the insert cells. On the contrary, YKL-40 (also known as chitinase-3-like-1 or cartilage glycoprotein39) had lower expression levels when compared to the $\mathrm{CE}$ and TM $[107,123]$.

Ideally, if the molecular signature of the stem-like cells is known, one can isolate and enrich the stem cell pool relatively easily using fluorescence-activated cell sorting (FACS) or magnetic immunosorting. However, the search of the specific stem cell signature will involve a laborious process and screening of a huge amount of putative markers. Hence, attempts have been made to isolate and propagate undifferentiated progenitor cells using a sphere culture protocol [124-126]. Precursors from human and rabbit CE have been successfully isolated using the sphere-forming assay and it was found that the peripheral CE contained significantly more precursors than the central region [127-130]. Mimura et al. proved that this culture assay selectively isolated younger progenies [131]. Huang and colleagues showed that bovine CE cells resembled bovine aorta in its content of endothelial colony forming cells [132]. Our sphere culture of primary peripheral bovine CE cells revealed the presence of undifferentiated precursor cells with self-renewal capacity and their potential to differentiate into neuronal lineages (Figures 4 and 5). Besides the CE, progenitor spheres were also isolated from human TM primary cultures [133]. It is likely that these isolated precursors from the CE and TM are from the transition zone in between them. It remains to be determined whether "Schwalbe's Line cells", "TM insert cells," and precursors having been isolated are the same cell type. For our convenience we have called the progenitor cells "PET cells" (Progenitors for Endothelium and Trabeculum) so not to presume until proven that we have the exact same cell population previously described. 


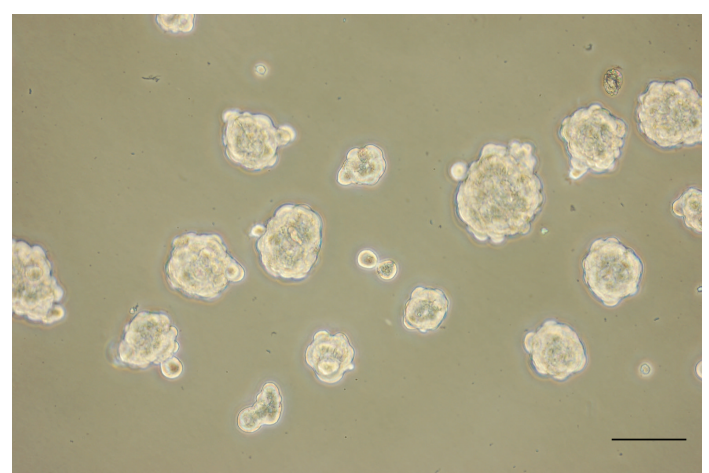

(a)

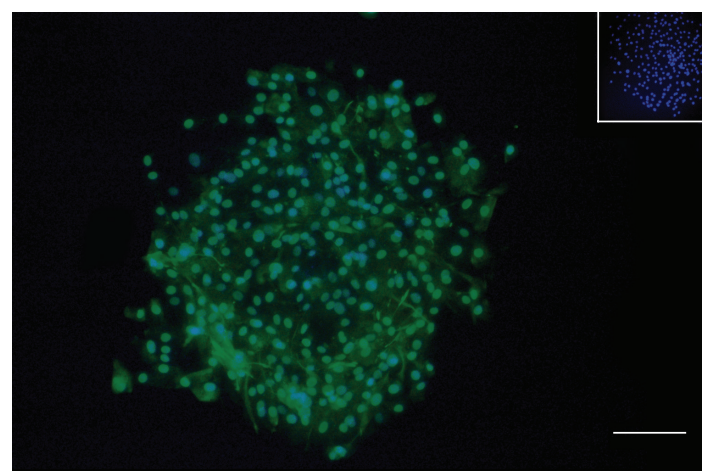

(c)

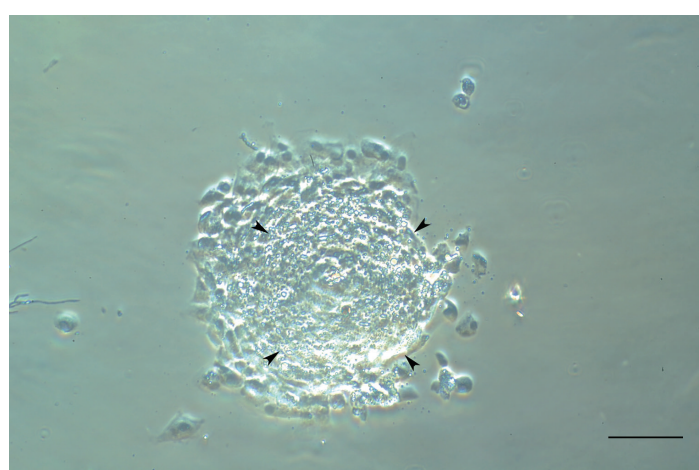

(b)

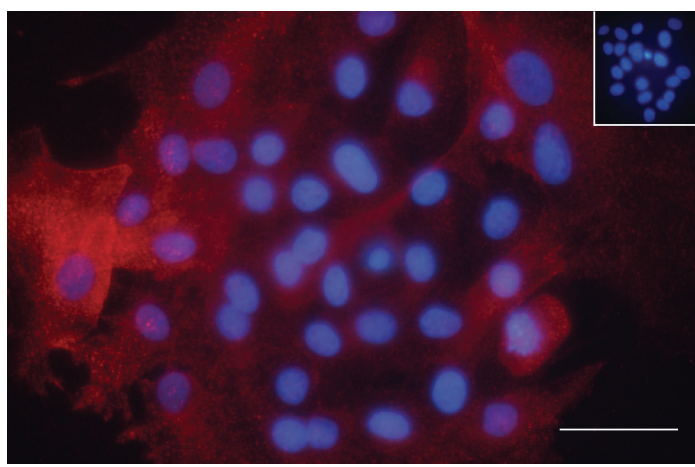

(d)

FIgURE 4: Sphere culture of bovine peripheral corneal endothelial cells. (a) Floating spheres on day 7 in defined serum-free media. Aggregation and development of dark cores can occur when spheres are left over the optimal culturing period of 5-7 days. (b) Cells migrating from an attached sphere on adherent substrate. The arrowheads show the contour of the sphere. (c) Nestin (green: undifferentiated cell marker) and (d) $\beta$-III tubulin (red: neuronal marker) staining were detected in the cells that migrated from the primary spheres. Nuclei were counterstained with DAPI (blue). Insets are negative controls with nonimmunized IgG. (a-c) Scale bar $=100 \mu \mathrm{m}$; (d) Scale bar $=50 \mu \mathrm{m}$.

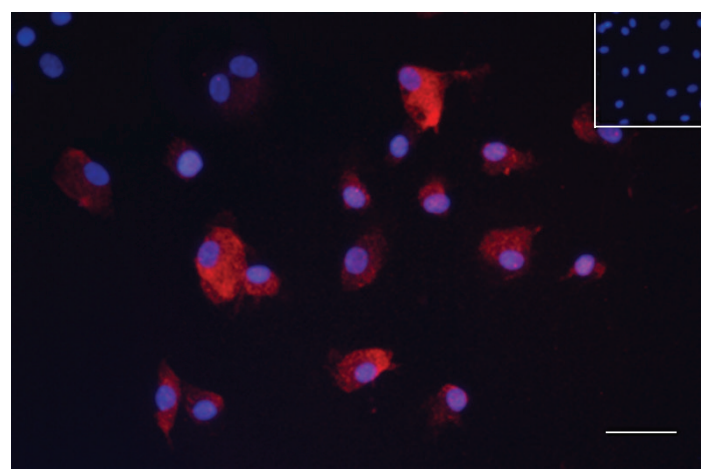

Figure 5: After 7 days of differentiation, cells derived from the spheres also expressed $\beta$-III tubulin. Nuclei were counterstained with DAPI (blue). The inset is a negative control with nonimmunized IgG. Scale bar $=50 \mu \mathrm{m}$.

The studies of stem cells in the eye have important implications in ocular health and disease treatment. Animal models using the isolated CE precursors for regeneration have been documented in several studies [59, 134, 135]. The PET cells within the transition area may be a promising cell source for replacing worn-out endothelium in vivo or boosting the number of endothelial cells in vitro on potential corneal graft materials. As mentioned in the previous section, ICE syndrome is manifested by abnormal proliferative CE cells that grow and cover the angle. It is tempting to speculate that the aberrant cells are metaplastic progenitors residing in the endothelium. Treatments can possibly be developed by targeting these cells. Besides, we know that the number of TM cells drops significantly in glaucoma patients, which precipitates the blockage of the aqueous outflow pathway. Thus, repopulating the cell-deficient TM using the PET cells may be a useful treatment to enhance drainage in glaucoma.

\section{Summary and Future Directions}

Recent progress in stem cell research provides an optimistic prospect on their use in regenerative medicine and tissue engineering. Specifically, advances in iPSCs and adult stem cells research raise hope for personalized cell replacement therapies. However, before iPSCs can be clinically applied, extensive efforts are needed to devise reliable production methods to address the safety concerns. In this paper, we summarized the accumulating evidence of the presence of putative stem cells in the transition zone between the peripheral CE and the anterior extension of the TM. We also 
discussed the origin and biological properties of both CE and TM cells. Up to now, there has been no clear definition of the progenitor cells located in the transition area. We have called the putative stem cells "PET cells" as they have the potential to replenish both the CE and TM. It remains to be determined whether the previously described "Schwalbe's Line cells" and "TM insert cells", as well as the precursors having been isolated, are of the same cell type; if they are, exactly what proliferation and differentiation potential do they retain, why do they not seem to repopulate the TM in glaucoma or the $\mathrm{CE}$ in age and disease when these populations are sorely depleted and finally how can they be used therapeutically?

Further research is required to establish the protocol to regulate cell division and differentiation of the PET cells towards appropriate lineages for repopulation of the diseased $\mathrm{CE}$ and TM. We need to identify which factors and signals govern their division and differentiation. Another challenge is the specific biomarker identification of the PET cells, which would facilitate stem cell isolation and enrichment. Furthermore, a better understanding of the migration and settlement properties of the PET cells is also important for the use of possible bioengineered materials. CE and TM cell loss is central to a number of ocular conditions including corneal diseases and glaucoma. In spite of the challenges, PET cells represent an attractive therapeutic stem cell source for the regeneration of the CE and TM. It is hoped that future research will ultimately lead to the development of stemcell-based therapies for CE diseases and glaucoma, which can reduce the requirement for corneal grafts and laser or surgical treatments in glaucomatous patients.

\section{References}

[1] M. Gnecchi, H. He, O. D. Liang et al., "Paracrine action accounts for marked protection of ischemic heart by Aktmodified mesenchymal stem cells," Nature Medicine, vol. 11, no. 4, pp. 367-368, 2005.

[2] M. Gnecchi, Z. Zhang, A. Ni, and V. J. Dzau, "Paracrine mechanisms in adult stem cell signaling and therapy," Circulation Research, vol. 103, no. 11, pp. 1204-1219, 2008.

[3] K. Takahashi and S. Yamanaka, "Induction of pluripotent stem cells from mouse embryonic and adult fibroblast cultures by defined factors," Cell, vol. 126, no. 4, pp. 663-676, 2006.

[4] M. Stadtfeld, M. Nagaya, J. Utikal, G. Weir, and K. Hochedlinger, "Induced pluripotent stem cells generated without viral integration," Science, vol. 322, no. 5903, pp. 945-949, 2008.

[5] H. Zhou, S. Wu, J. Y. Joo et al., "Generation of induced pluripotent stem cells using recombinant proteins," Cell Stem Cell, vol. 4, no. 6, p. 581, 2009.

[6] T. Lin, R. Ambasudhan, X. Yuan et al., "A chemical platform for improved induction of human iPSCs," Nature Methods, vol. 6, no. 11, pp. 805-808, 2009.

[7] J. M. Polo, S. Liu, M. E. Figueroa et al., "Cell type of origin influences the molecular and functional properties of mouse induced pluripotent stem cells," Nature Biotechnology, vol. 28, no. 8, pp. 848-855, 2010.
[8] K. Kim, A. Doi, B. Wen et al., "Epigenetic memory in induced pluripotent stem cells," Nature, vol. 467, no. 7313, pp. 285290, 2010.

[9] M. Mimeault and S. K. Batra, "Recent progress on tissueresident adult stem cell biology and their therapeutic implications," Stem Cell Reviews, vol. 4, no. 1, pp. 27-49, 2008.

[10] M. Mimeault, R. Hauke, and S. K. Batra, "Stem cells: a revolution in therapeutics-recent advances in stem cell biology and their therapeutic applications in regenerative medicine and cancer therapies," Clinical Pharmacology and Therapeutics, vol. 82, no. 3, pp. 252-264, 2007.

[11] D. Lodi, T. Iannitti, and B. Palmieri, "Stem cells in clinical practice: applications and warnings," Journal of Experimental and Clinical Cancer Research, vol. 30, no. 1, p. 9, 2011.

[12] R. E. MacLaren, R. A. Pearson, A. MacNeil et al., "Retinal repair by transplantation of photoreceptor precursors," Nature, vol. 444, no. 7116, pp. 203-207, 2006.

[13] G. A. Limb and J. T. Daniels, "Ocular regeneration by stem cells: present status and future prospects," British Medical Bulletin, vol. 85, no. 1, pp. 47-61, 2008.

[14] G. Pellegrini, C. E. Traverso, A. T. Franzi, M. Zingirian, R. Cancedda, and M. De Luca, "Long-term restoration of damaged corneal surfaces with autologous cultivated corneal epithelium," The Lancet, vol. 349, no. 9057, pp. 990-993, 1997.

[15] G. A. Limb, J. T. Daniels, A. D. Cambrey et al., "Current prospects for adult stem cell-based therapies in ocular repair and regeneration," Current Eye Research, vol. 31, no. 5, pp. 381-390, 2006.

[16] V. Marchetti, T. U. Krohne, D. F. Friedlander, and M. Friedlander, "Stemming vision loss with stem cells," Journal of Clinical Investigation, vol. 120, no. 9, pp. 3012-3021, 2010.

[17] D. J. J. Park and J. W. Karesh, "Topographic anatomy of the eye: an overview," in Duane's Foundations of Clinical Ophthalmology, W. Tasman and E. A. Jaeger, Eds., vol. 1, Lippincott Williams \& Wilkins, Philadelphia, Pa, USA, 2011.

[18] H. F. Edelhauser and J. L. Ubels, "The cornea and the sclera," in Adler's Physiology of the Eye, P. L. Kaufman and A. Alm, Eds., chapter 4, Mosby, St. Louis, Mo, USA, 10th edition, 2003.

[19] G. O. Waring III, W. M. Bourne, H. F. Edelhauser, and K. R. Kenyon, "The corneal endothelium. Normal and pathologic structure and function," Ophthalmology, vol. 89, no. 6, pp. 531-590, 1982.

[20] B. A. T. Gabelt and P. L. Kaufman, "Aqueous humor hydrodynamics," in Adler's Physiology of the Eye, P. L. Kaufman and A. Alm, Eds., chapter 6, Mosby, St. Louis, Mo, USA, 10th edition, 2003.

[21] E. R. Tamm, "The trabecular meshwork outflow pathways: structural and functional aspects," Experimental Eye Research, vol. 88, no. 4, pp. 648-655, 2009.

[22] E. Lutjen-Drecoll and J. W. Rohen, "Functional morphology of the trabecular meshwork," in Duane's Foundations of Clinical Ophthalmology, W. Tasman and E. A. Jaeger, Eds., vol. 1, chapter 10, Lippincott Williams \& Wilkins, Philadelphia, Pa, USA, 2011.

[23] W. M. Grant, "Experimental aqueous perfusion in enucleated human eyes," Archives of Ophthalmology, vol. 69, pp. 783801, 1963.

[24] Y. R. Barishak, Embryology of the Eye and its Adnexa, Karger, New York, NY, USA, 2nd edition, 2001. 
[25] C. S. Cook, V. Ozanics, and F. A. Jakobiec, "Prenatal development of the eye and it's adnexa," in Duane's Foundations of Clinical Ophthalmology, W. Tasman and E. A. Jaeger, Eds., vol. 1, chapter 2, Lippincott Williams \& Wilkins, Philadelphia, Pa, USA, 2011.

[26] A. Cvekl and E. R. Tamm, "Anterior eye development and ocular mesenchyme: new insights from mouse models and human diseases," BioEssays, vol. 26, no. 4, pp. 374-386, 2004.

[27] D. R. Anderson, "The development of the trabecular meshwork and its abnormality in primary infantile glaucoma," Transactions of the American Ophthalmological Society, vol. 79, pp. 458-485, 1981.

[28] W. J. Gehring and K. Ikeo, "Pax 6: mastering eye morphogenesis and eye evolution," Trends in Genetics, vol. 15, no. 9, pp. 371-377, 1999.

[29] R. L. Chow and R. A. Lang, "Early eye development in vertebrates," Annual Review of Cell and Developmental Biology, vol. 17, pp. 255-296, 2001.

[30] D. C. Baulmann, A. Ohlmann, C. Flügel-Koch, S. Goswami, A. Cvekl, and E. R. Tamm, "Pax6 heterozygous eyes show defects in chamber angle differentiation that are associated with a wide spectrum of other anterior eye segment abnormalities," Mechanisms of Development, vol. 118, no. 1-2, pp. 3-17, 2002.

[31] J. M. Collinson, J. C. Quinn, R. E. Hill, and J. D. West, "The roles of Pax6 in the cornea, retina, and olfactory epithelium of the developing mouse embryo," Developmental Biology, vol. 255, no. 2, pp. 303-312, 2003.

[32] K. Kitamura, H. Miura, S. Miyagawa-Tomita et al., "Mouse Pitx2 deficiency leads to anomalies of the ventral body wall, heart, extra-and periocular mesoderm and right pulmonary isomerism," Development, vol. 126, no. 24, pp. 5749-5758, 1999.

[33] S. H. Kidson, T. Kume, K. Deng, V. Winfrey, and B. L. M. Hogan, "The forkhead/winged-helix gene, Mf1, is necessary for the normal development of the cornea and formation of the anterior chamber in the mouse eye," Developmental Biology, vol. 211, no. 2, pp. 306-322, 1999.

[34] A. L. Evans and P. J. Gage, "Expression of the homeobox gene Pitx2 in neural crest is required for optic stalk and ocular anterior segment development," Human Molecular Genetics, vol. 14, no. 22, pp. 3347-3359, 2005.

[35] J. C. Sowden, "Molecular and developmental mechanisms of anterior segment dysgenesis," Eye, vol. 21, no. 10, pp. 1310 1318, 2007.

[36] P. Liu and R. L. Johnson, "Lmx1b is required for murine trabecular meshwork formation and for maintenance of corneal transparency," Developmental Dynamics, vol. 239, no. 8, pp. 2161-2171, 2010.

[37] D. B. Gould, R. S. Smith, and S. W. John, "Anterior segment development relevant to glaucoma," International Journal of Developmental Biology, vol. 48, no. 8-9, pp. 1015-1029, 2004.

[38] P. J. Gage and A. L. Zacharias, "Signaling "cross-talk" is integrated by transcription factors in the development of the anterior segment in the eye," Developmental Dynamics, vol. 238, no. 9, pp. 2149-2162, 2009.

[39] A. Wurm, E. Sock, R. Fuchshofer, M. Wegner, and E. R. Tamm, "Anterior segment dysgenesis in the eyes of mice deficient for the high-mobility-group transcription factor Sox11," Experimental Eye Research, vol. 86, no. 6, pp. 895907, 2008.

[40] Y.-W. Hsieh, X.-M. Zhang, E. Lin, G. Oliver, and X.-J. Yang, "The homeobox gene Six3 is a potential regulator of anterior segment formation in the chick eye," Developmental Biology, vol. 248, no. 2, pp. 265-280, 2002.

[41] J. Z. McHenry, A. Leon, K. I. Matthaei, and D. R. Cohen, "Overexpression of fra-2 in transgenic mice perturbs normal eye development," Oncogene, vol. 17, no. 9, pp. 1131-1140, 1998.

[42] L. P. Sanford, I. Ormsby, A. C. Gittenberger-de Groot et al., "TGF $\beta 2$ knockout mice have multiple developmental defects that are non-overlapping with other TGF $\beta$ knockout phenotypes," Development, vol. 124, no. 13, pp. 2659-2670, 1997.

[43] S. Saika, S. Saika, C.-Y. Liu et al., "Tgf $\beta 2$ in corneal morphogenesis during mouse embryonic development," Developmental Biology, vol. 240, no. 2, pp. 419-432, 2001.

[44] B. Chang, R. S. Smith, M. Peters et al., "Haploinsufficient Bmp4 ocular phenotypes include anterior segment dysgenesis with elevated intraocular pressure," BMC Genetics, vol. 2, article 18, 2001.

[45] B. J. Tripathi, R. C. Tripathi, A. M. Livingston, and N. S. Borisuth, "The role of growth factors in the embryogenesis and differentiation of the eye," American Journal of Anatomy, vol. 192, no. 4, pp. 442-471, 1991.

[46] W. M. Petroll, J. V. Jester, P. Barry-Lane, and H. D. Cavanagh, "Assessment of f-actin organization and apical-basal polarity during in vivo cat endothelial wound healing," Investigative Ophthalmology and Visual Science, vol. 36, no. 12, pp. 24922502, 1995.

[47] A. K. Shamsuddin, V. S. Nirankari, D. M. Purnell, and S. H. Chang, "Is the corenal posterior cell layer truly endothelial?" Ophthalmology, vol. 93, no. 10, pp. 1298-1303, 1986.

[48] L. A. Risen, P. S. Binder, and S. K. Nayak, "Intermediate filaments and their organization in human corneal endothelium," Investigative Ophthalmology and Visual Science, vol. 28, no. 12, pp. 1933-1938, 1987.

[49] B. Foets, J. Van den Oord, K. Engelmann, and L. Missotten, "A comparative immunohistochemical study of human corneotrabecular tissue," Graefe's Archive for Clinical and Experimental Ophthalmology, vol. 230, no. 3, pp. 269-274, 1992.

[50] B. J. Foets, J. J. Van den Oord, R. Volpes, and L. Missotten, "In situ immunohistochemical analysis of cell adhesion molecules on human corneal endothelial cells," British Journal of Ophthalmology, vol. 76, no. 4, pp. 205-209, 1992.

[51] B. J. Foets, J. J. Van den Oord, V. J. Desmet, and L. Missotten, "Cytoskeletal filament typing of human corneal endothelial cells," Cornea, vol. 9, no. 4, pp. 312-317, 1990.

[52] M. Kasper, P. Stosiek, and B. Lane, "Cytokeratin and vimentin heterogeneity in human cornea," Acta Histochemica, vol. 93, no. 2, pp. 371-381, 1992.

[53] S. Merjava, A. Neuwirth, V. Mandys, and K. Jirsova, "Cytokeratins 8 and 18 in adult human corneal endothelium," Experimental Eye Research, vol. 89, no. 3, pp. 426-431, 2009.

[54] T. R. Kramer, H. E. Grossniklaus, N. Vigneswaran, G. O. Waring, and A. Kozarsky, "Cytokeratin expression in corneal endothelium in the iridocorneal endothelial syndrome," Investigative Ophthalmology and Visual Science, vol. 33, no. 13, pp. 3581-3585, 1992.

[55] G. C. Cockerham, N. V. Laver, A. A. Hidayat, and D. L. McCoy, "An immunohistochemical analysis and comparison of posterior polymorphous dystrophy with congenital hereditary endothelial dystrophy," Cornea, vol. 21, no. 8, pp. 787791, 2002. 
[56] K. Jirsova, S. Merjava, R. Martincova et al., "Immunohistochemical characterization of cytokeratins in the abnormal corneal endothelium of posterior polymorphous corneal dystrophy patients," Experimental Eye Research, vol. 84, no. 4, pp. 680-686, 2007.

[57] S. Hodson and C. Wigham, "The permeability of rabbit and human corneal endothelium," Journal of Physiology, vol. 342, pp. 409-419, 1983.

[58] T. Mimura, S. Yamagami, S. Yokoo et al., "Cultured human corneal endothelial cell transplantation with a collagen sheet in a rabbit model," Investigative Ophthalmology and Visual Science, vol. 45, no. 9, pp. 2992-2997, 2004.

[59] T. Mimura, S. Yokoo, M. Araie, S. Amano, and S. Yamagami, "Treatment of rabbit bullous keratopathy with precursors derived from cultured human corneal endothelium," Investigative Ophthalmology and Visual Science, vol. 46, no. 10, pp. 3637-3644, 2005.

[60] I. Grierson and W. R. Lee, "Junctions between the cells of the trabecular meshwork," Albrecht von Graefes Archiv fur Klinische und Experimentelle Ophthalmologie, vol. 192, no. 2, pp. 89-104, 1974.

[61] M. J. Hoare, I. Grierson, D. Brotchie, N. Pollock, K. Cracknell, and A. F. Clark, "Cross-linked actin networks (CLANs) in the trabecular meshwork of the normal and glaucomatous human eye in situ," Investigative Ophthalmology and Visual Science, vol. 50, no. 3, pp. 1255-1263, 2009.

[62] N. C. Wade, I. Grierson, S. O’Reilly et al., "Cross-linked actin networks (CLANs) in bovine trabecular meshwork cells," Experimental Eye Research, vol. 89, no. 5, pp. 648-659, 2009.

[63] I. K. Gipson and R. A. Anderson, "Actin filaments in cells of human trabecular meshwork and Schlemm's canal," Investigative Ophthalmology and Visual Science, vol. 18, no. 6, pp. 547-561, 1979.

[64] W. D. Stamer, R. E. Seftor, R. W. Snyder, and J. W. Regan, "Cultured human trabecular meshwork cells express aquaporin-1 water channels," Current Eye Research, vol. 14, no. 12, pp. 1095-1100, 1995.

[65] I. L. Chang, G. Elner, Y. J. Yue, A. Cornicelli, J. E. Kawa, and V. M. Elner, "Expression of modified low-density lipoprotein receptors by trabecular meshwork cells," Current Eye Research, vol. 10, no. 12, pp. 1101-1112, 1991.

[66] W. D. Stamer, Y. Huang, R. E. Seftor, S. S. Svensson, R. W. Snyder, and J. W. Regan, "Cultured human trabecular meshwork cells express functional $\alpha 2$ A adrenergic receptors," Investigative Ophthalmology and Visual Science, vol. 37, no. 12, pp. 2426-2433, 1996.

[67] J. Z. Gasiorowski and P. Russell, "Biological properties of trabecular meshwork cells," Experimental Eye Research, vol. 88, no. 4, pp. 671-675, 2009.

[68] P. Gonzalez, M. Caballero, P. B. Liton, W. D. Stamer, and D. L. Epstein, "Expression analysis of the matrix GLA protein and VE-cadherin gene promoters in the outflow pathway," Investigative Ophthalmology and Visual Science, vol. 45, no. 5, pp. 1389-1395, 2004.

[69] P. B. Liton, X. Liu, W. D. Stamer, P. Challa, D. L. Epstein, and P. Gonzalez, "Specific targeting of gene expression to a subset of human trabecular meshwork cells using the chitinase 3-like 1 promoter," Investigative Ophthalmology and Visual Science, vol. 46, no. 1, pp. 183-190, 2005.

[70] J. Rohen and E. van der Zypen, "The phagocytic activity of the trabecular meshwork endothelium," Albrecht von Graefe's Archive for Clinical and Experimental Ophthalmology, vol. 175, no. 2, pp. 143-160, 1968.
[71] I. Grierson, "The outflow system in health and disease," Bulletin de la Societe Belge d'Ophtalmologie, vol. 225, part 2, pp. 1-43, 1987.

[72] T. S. Acott and M. J. Kelley, "Extracellular matrix in the trabecular meshwork," Experimental Eye Research, vol. 86, no. 4, pp. 543-561, 2008.

[73] A. Ringvold, "Actin filaments in trabecular endothelial cells in eyes of the vervet monkey (Cercopithecus aethiops)," Acta Ophthalmologica, vol. 56, no. 2, pp. 217-225, 1978.

[74] I. Grierson and A. H. Rahi, "Microfilaments in the cells of the human trabecular meshwork," British Journal of Ophthalmology, vol. 63, no. 1, pp. 3-8, 1979.

[75] M. Wiederholt, S. Bielka, F. Schweig, E. Lutjen-Drecoll, and A. Lepple-Wienhues, "Regulation of outflow rate and resistance in the perfused anterior segment of the bovine eye," Experimental Eye Research, vol. 61, no. 2, pp. 223-234, 1995.

[76] N. C. Joyce, "Proliferative capacity of the corneal endothelium," Progress in Retinal and Eye Research, vol. 22, no. 3, pp. 359-389, 2003.

[77] I. Grierson and P. Hogg, "The proliferative and migratory activities of trabecular meshwork cells," Progress in Retinal and Eye Research, vol. 15, no. 1, pp. 33-67, 1995.

[78] I. Grierson, E. Robins, W. Unger, L. Millar, and A. Ahmed, "The cells of the bovine outflow system in tissue culture," Experimental Eye Research, vol. 40, no. 1, pp. 35-46, 1985.

[79] W. M. Bourne, L. R. Nelson, and D. O. Hodge, "Central corneal endothelial cell changes over a ten-year period," Investigative Ophthalmology and Visual Science, vol. 38, no. 3, pp. 779-782, 1997.

[80] J. J. Kanski, “Cornea," in Clinical Ophthalmology : a Systematic Approach, chapter 9, Elsevier Butterworth-Heinemann, Edinburgh, UK, 6th edition, 2007.

[81] J. J. Kanski, "Glaucoma," in Clinical Ophthalmology : a Systematic Approach, chapter 13, Elsevier ButterworthHeinemann, Edinburgh, UK, 6th edition, 2007.

[82] D. N. Howell, T. Damms, J. L. Burchette Jr., and W. R. Green, "Endothelial metaplasia in the iridocorneal endothelial syndrome," Investigative Ophthalmology and Visual Science, vol. 38, no. 9, pp. 1896-1901, 1997.

[83] J. Alvarado, C. Murphy, J. Polansky, and R. Juster, "Agerelated changes in trabecular meshwork cellularity," Investigative Ophthalmology and Visual Science, vol. 21, no. 5, pp. 714-727, 1981.

[84] I. Grierson and R. C. Howes, "Age-related depletion of the cell population in the human trabecular meshwork," Eye, vol. 1, no. 2, pp. 204-210, 1987.

[85] J. Alvarado, C. Murphy, and R. Juster, “Trabecular meshwork cellularity in primary open angle glaucoma and nonglaucomatous normals," Ophthalmology, vol. 91, no. 6, pp. 564-579, 1984.

[86] K. Engelmann and P. Friedl, "Optimization of culture conditions for human corneal endothelial cells," In Vitro Cellular and Developmental Biology, vol. 25, no. 11, pp. 10651072, 1989.

[87] J. R. Polansky, R. N. Weinreb, J. D. Baxter, and J. Alvarado, "Human trabecular cells. I. Establishment in tissue culture and growth characteristics," Investigative Ophthalmology and Visual Science, vol. 18, no. 10, pp. 1043-1049, 1979.

[88] V. P. T. Hoppenreijs, E. Pels, G. F. J. M. Vrensen, and W. F. Treffers, "Corneal endothelium and growth factors," Survey of Ophthalmology, vol. 41, no. 2, pp. 155-164, 1996. 
[89] S. E. Wilson, J. W. Walker, E. L. Chwang, and Y. G. He, "Hepatocyte growth factor, keratinocyte growth factor, their receptors, fibroblast growth factor receptor-2, and the cells of the cornea," Investigative Ophthalmology and Visual Science, vol. 34, no. 8, pp. 2544-2561, 1993.

[90] I. Grierson, L. Heathcote, P. Hiscott, P. Hogg, M. Briggs, and S. Hagan, "Hepatocyte growth factor/scatter factor in the eye," Progress in Retinal and Eye Research, vol. 19, no. 6, pp. 779-802, 2000.

[91] L. Hyldahl, "Control of cell proliferation in the human embryonic cornea: an autoradiographic analysis of the effect of growth factors on DNA synthesis in endothelial and stromal cells in organ culture and after explantation in vitro," Journal of Cell Science, vol. 83, pp. 1-21, 1986.

[92] M. Tamura and Y. Iwamoto, "The effect of platelet-derived growth factor on phagocytosis of cultured human trabecular cells," Experimental Eye Research, vol. 48, no. 6, pp. 761-770, 1989.

[93] A. Ando, S. Kaneko, and M. Matsumura, "The effect of growth factors on the proliferation of cultured porcine trabecular meshwork cells," Nippon Ganka Gakkai Zasshi, vol. 108, no. 9, pp. 549-553, 2004.

[94] K. H. Chen, D. L. Harris, and N. C. Joyce, "TGF- $\beta 2$ in aqueous humor suppresses S-phase entry in cultured corneal endothelial cells," Investigative Ophthalmology and Visual Science, vol. 40, no. 11, pp. 2513-2519, 1999.

[95] J. Li, B. J. Tripathi, K. V. Chalam, and R. C. Tripathi, "Transforming growth factor- $\beta 1$ and $-\beta 2$ positively regulate TGF- $\beta 1 \mathrm{mRNA}$ expression in trabecular cells," Investigative Ophthalmology and Visual Science, vol. 37, no. 13, pp. 27782782, 1996.

[96] M. R. Alison, R. Poulsom, S. Forbes, and N. A. Wright, "An introduction to stem cells," The Journal of Pathology, vol. 197, no. 4, pp. 457-467, 2002.

[97] M. Boulton and J. Albon, "Stem cells in the eye," International Journal of Biochemistry and Cell Biology, vol. 36, no. 4, pp. 643-657, 2004.

[98] G. Raviola, "Schwalbe line's cells: a new cell type in the trabecular meshwork of Macaca mulatta," Investigative Ophthalmology and Visual Science, vol. 22, no. 1, pp. 45-56, 1982.

[99] R. A. Stone, Y. Kuwayama, A. M. Laties, and P. J. Marangos, "Neuron-specific enolase-containing cells in the rhesus monkey trabecular meshwork," Investigative Ophthalmology and Visual Science, vol. 25, no. 11, pp. 1332-1334, 1984.

[100] M. Rittig, C. Flugel, P. Prehm, and E. Lütjen-Drecoll, "Hyaluronan synthase immunoreactivity in the anterior segment of the primate eye," Graefe's Archive for Clinical and Experimental Ophthalmology, vol. 231, no. 6, pp. 313-317, 1993.

[101] D. Samuelson, C. Plummer, P. Lewis, and K. Gelatt, "Schwalbe line's cell in the normal and glaucomatous dog," Veterinary Ophthalmology, vol. 4, no. 1, pp. 47-53, 2001.

[102] T. S. Acott, J. R. Samples, J. M. Bradley, D. R. Bacon, S. S. Bylsma, and E. M. Van Buskirk, "Trabecular repopulation by anterior trabecular meshwork cells after laser trabeculoplasty," American Journal of Ophthalmology, vol. 107, no. 1, pp. 1-6, 1989.

[103] J. B. Wise and S. L. Witter, "Argon laser therapy for openangle glaucoma. A pilot study," Archives of Ophthalmology, vol. 97, no. 2, pp. 319-322, 1979.

[104] J. D. Stein and P. Challa, "Mechanisms of action and efficacy of argon laser trabeculoplasty and selective laser trabeculoplasty," Current Opinion in Ophthalmology, vol. 18, no. 2, pp. 140-145, 2007.
[105] D. K. Dueker, M. Norberg, D. H. Johnson, R. C. Tschumper, and L. Feeney-Burns, "Stimulation of cell division by argon and Nd:YAG laser trabeculoplasty in cynomolgus monkeys," Investigative Ophthalmology and Visual Science, vol. 31, no. 1, pp. 115-124, 1990.

[106] M. W. Kimpel and D. H. Johnson, "Factors influencing in vivo trabecular cell replication as determined by $3 \mathrm{H}-$ thymidine labelling; An autoradiographic study in cats," Current Eye Research, vol. 11, no. 4, pp. 297-306, 1992.

[107] M. J. Kelley, A. Y. Rose, K. E. Keller, H. Hessle, J. R. Samples, and T. S. Acott, "Stem cells in the trabecular meshwork: present and future promises," Experimental Eye Research, vol. 88, no. 4, pp. 747-751, 2009.

[108] M. M. Rodrigues, G. L. Spaeth, and P. Donohoo, "Electron microscopy of argon laser therapy in phakic open-angle glaucoma," Ophthalmology, vol. 89, no. 3, pp. 198-210, 1982.

[109] R. A. Alexander and I. Grierson, "Morphological effects of argon laser trabeculoplasty upon the glaucomatous human meshwork," Eye, vol. 3, part 6, pp. 719-726, 1989.

[110] R. A. Alexander, I. Grierson, and W. H. Church, "The effect of argon laser trabeculoplasty upon the normal human trabecular meshwork," Graefe's Archive for Clinical and Experimental Ophthalmology, vol. 227, no. 1, pp. 72-77, 1989.

[111] J. Amann, G. P. Holley, S. B. Lee, and H. F. Edelhauser, "Increased endothelial cell density in the paracentral and peripheral regions of the human cornea," American Journal of Ophthalmology, vol. 135, no. 5, pp. 584-590, 2003.

[112] B. Schimmelpfennig, "Direct and indirect determination of nonuniform cell density distribution in human corneal endothelium," Investigative Ophthalmology and Visual Science, vol. 25, no. 2, pp. 223-229, 1984.

[113] R. A. Laing, L. Neubauer, and S. S. Oak, "Evidence for mitosis in the adult corneal endothelium," Ophthalmology, vol. 91, no. 10, pp. 1129-1134, 1984.

[114] W. F. Treffers, "Human corneal endothelial wound repair. In vitro and in vivo," Ophthalmology, vol. 89, no. 6, pp. 605-613, 1982.

[115] L. Gan, P. Fagerholm, and S. Ekenbark, "Expression of proliferating cell nuclear antigen in corneas kept in long term culture," Acta Ophthalmologica Scandinavica, vol. 76, no. 3, pp. 308-313, 1998.

[116] K. Engelmann, J. Bednarz, and M. Bohnke, "Endothelial cell transplantation and growth behavior of the human corneal endothelium," Ophthalmologe, vol. 96, no. 9, pp. 555-562, 1999.

[117] T. Mimura and N. C. Joyce, "Replication competence and senescence in central and peripheral human corneal endothelium," Investigative Ophthalmology and Visual Science, vol. 47, no. 4, pp. 1387-1396, 2006.

[118] K. A. Williams, D. Roder, A. Esterman, S. M. Muehlberg, and D. J. Coster, "Factors predictive of corneal graft survival: report from the Australian corneal graft registry," Ophthalmology, vol. 99, no. 3, pp. 403-414, 1992.

[119] C. Balachandran, L. Ham, C. A. Verschoor, T. S. Ong, J. van der Wees, and G. R. J. Melles, "Spontaneous corneal clearance despite graft detachment in descemet membrane endothelial keratoplasty," American Journal of Ophthalmology, vol. 148, no. 2, pp. 227-234, 2009.

[120] J. Schwartzkopff, L. Bredow, S. Mahlenbrey, D. Boehringer, and T. Reinhard, "Regeneration of corneal endothelium following complete endothelial cell loss in rat keratoplasty," Molecular Vision, vol. 16, pp. 2368-2375, 2010. 
[121] D. R. Whikehart, C. H. Parikh, A. V. Vaughn, K. Mishler, and H. F. Edelhauser, "Evidence suggesting the existence of stem cells for the human corneal endothelium," Molecular Vision, vol. 11, pp. 816-824, 2005.

[122] S. L. McGowan, H. F. Edelhauser, R. R. Pfister, and D. R. Whikehart, "Stem cell markers in the human posterior limbus and corneal endothelium of unwounded and wounded corneas," Molecular Vision, vol. 13, pp. 1984-2000, 2007.

[123] M. J. Kelly, K. E. Keller, J. R. Samples, and T. S. Acott, "Immunocharacterization of the trabecular meshwork insert region: the search for a TM stem cell," in Proceedings of the ARVO Annual Meeting, Fort Lauderdale, Fla, USA, May 2006.

[124] B. A. Reynolds and S. Weiss, "Generation of neurons and astrocytes from isolated cells of the adult mammalian central nervous system," Science, vol. 255, no. 5052, pp. 1707-1710, 1992.

[125] B. L. Coles, B. Angenieux, T. Inoue et al., "Facile isolation and the characterization of human retinal stem cells," Proceedings of the National Academy of Sciences of the United States of America, vol. 101, no. 44, pp. 15772-15777, 2004.

[126] H. Li, H. Liu, and S. Heller, "Pluripotent stem cells from the adult mouse inner ear," Nature Medicine, vol. 9, no. 10, pp. 1293-1299, 2003.

[127] S. Yokoo, S. Yamagami, Y. Yanagi et al., "Human corneal endothelial cell precursors isolated by sphere-forming assay," Investigative Ophthalmology and Visual Science, vol. 46, no. 5, pp. 1626-1631, 2005.

[128] T. Mimura, S. Yamagami, S. Yokoo, M. Araie, and S. Amano, "Comparison of rabbit corneal endothelial cell precursors in the central and peripheral cornea," Investigative Ophthalmology and Visual Science, vol. 46, no. 10, pp. 3645-3648, 2005.

[129] S. Amano, S. Yamagami, T. Mimura, S. Uchida, and S. Yokoo, "Corneal stromal and endothelial cell precursors," Cornea, vol. 25, no. 10, supplement 1, pp. S73-S77, 2006.

[130] S. Yamagami, S. Yokoo, T. Mimura, T. Takato, M. Araie, and S. Amano, "Distribution of precursors in human corneal stromal cells and endothelial cells," Ophthalmology, vol. 114, no. 3, pp. 433-439, 2007.

[131] T. Mimura, S. Yamagami, S. Yokoo, T. Usui, and S. Amano, "Selective isolation of young cells from human corneal endothelium by the sphere-forming assay," Tissue Engineering $C$, vol. 16, no. 4, pp. 803-812, 2010.

[132] L. Huang, M. Harkenrider, M. Thompson et al., "A hierarchy of endothelial colony-forming cell activity displayed by bovine corneal endothelial cells," Investigative Ophthalmology \& Visual Science, vol. 51, no. 8, pp. 3943-3949, 2010.

[133] P. Gonzalez, D. L. Epstein, C. Luna, and P. B. Liton, "Characterization of free-floating spheres from human trabecular meshwork (HTM) cell culture in vitro," Experimental Eye Research, vol. 82, no. 6, pp. 959-967, 2006.

[134] T. Mimura, S. Yamagami, S. Yokoo et al., "Sphere therapy for corneal endothelium deficiency in a rabbit model," Investigative Ophthalmology and Visual Science, vol. 46, no. 9, pp. 3128-3135, 2005.

[135] S. Yamagami, T. Mimura, S. Yokoo, T. Takato, and S. Amano, "Isolation of human corneal endothelial cell precursors and construction of cell sheets by precursors," Cornea, vol. 25, no. 10, supplement 1, pp. S90-S92, 2006. 

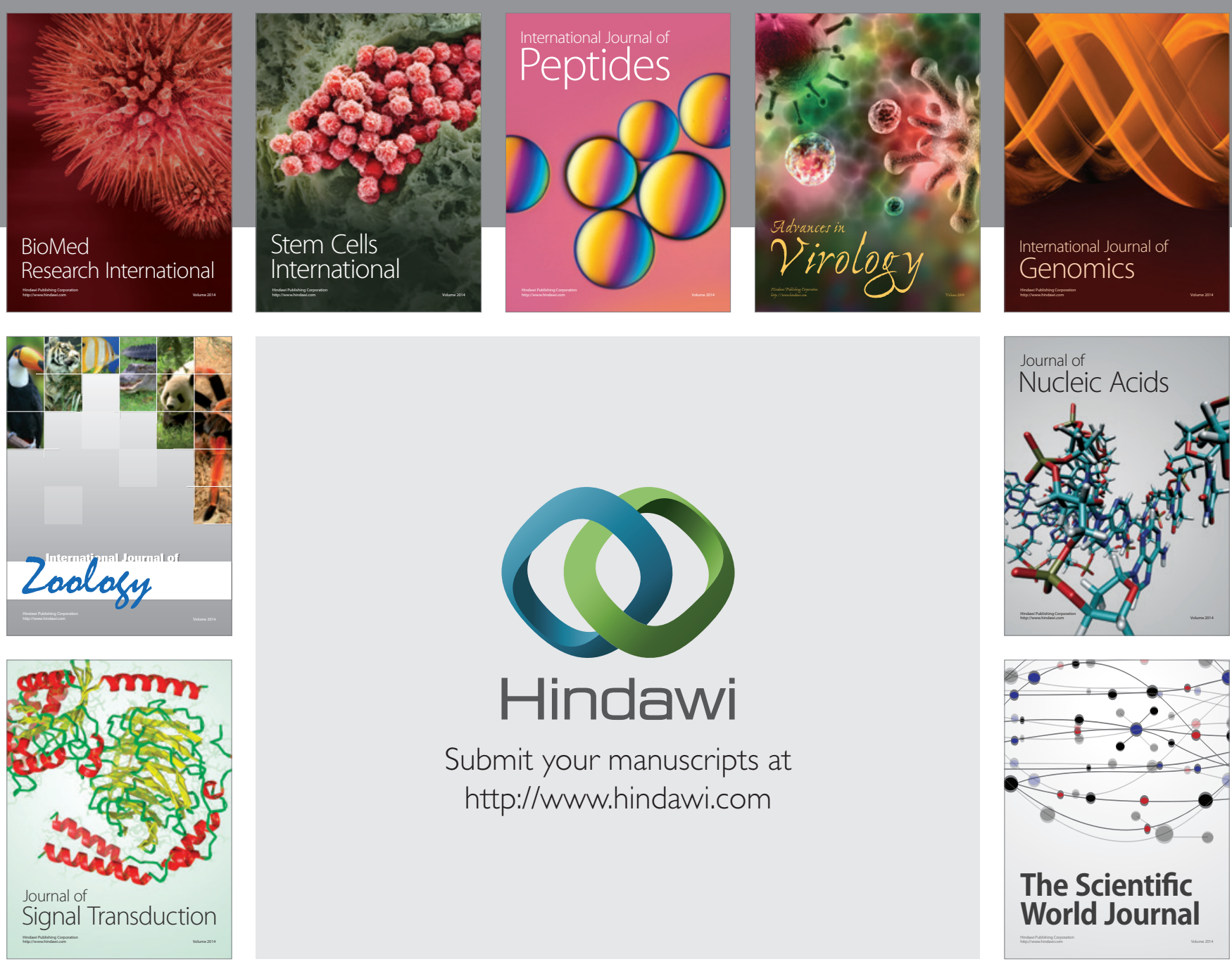

Submit your manuscripts at

http://www.hindawi.com


The Scientific World Journal
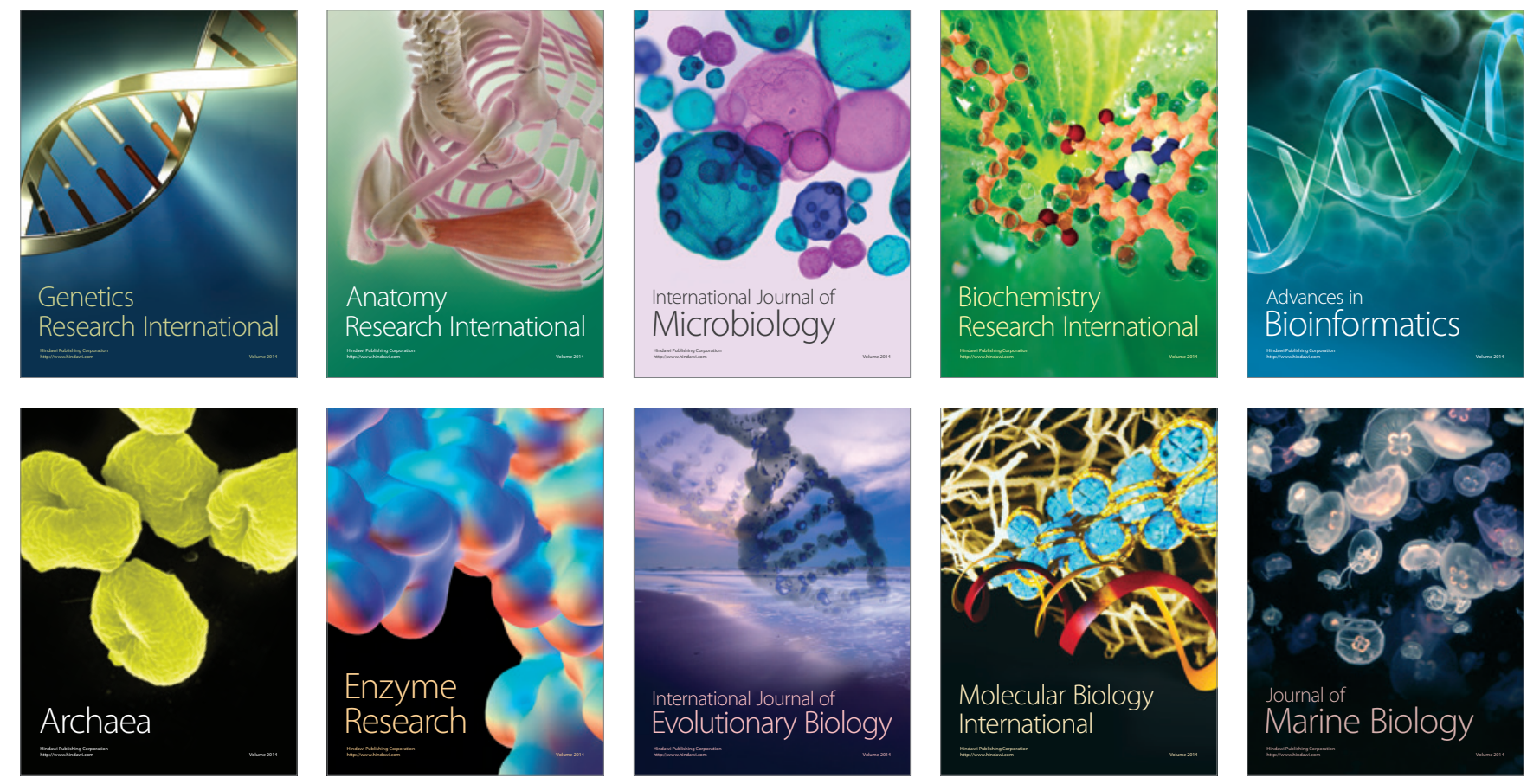